\title{
The Need of Professional Judgement of the Accountant in Accounting Assets of Exploration and Evaluation of Mineral Resources
}

\author{
Kulikova L.I. \\ Kazan Federal University, Institute of Management, Economics and Finance, Kazan, 420008, Russia \\ Gubaidullina A.R. \\ Kazan Federal University, Institute of Management, Economics and Finance, Kazan, 420008, Russia \\ Arzhantseva N.V. \\ Kazan Federal University, Institute of Language, 420008, Kazan, Russia
}

\section{Doi:10.5901/mjss.2014.v5n24p65}

\begin{abstract}
The relevance of the investigation is predetermined by the fact that application of IFRS 6 "The exploration for and evaluation of mineral resources" presupposes the application of professional accounting judgment while running the information about exploration and evaluation of mineral resources. The aim of the article is to study how oil producing companies apply IFRS 6 and to work out some suggestions on perfecting the accounting policy in the above-mentioned assets in the conditions of uncertainty of the norms of International standards.
\end{abstract}

Keywords: professional accounting judgment, the accounting of minerals, assets exploration and evaluation, IFRS 6

\section{Introduction}

The necessity to single out the assets of prospection and evaluation of mineral resources into a separate category is predetermined by the absence of the economic benefits revenue into the organization of these very assets in the process of their exploitation and also by the ambiguity of the future economic benefits. So, if an organization applied the general criteria to recognize fixed or intangible assets, set in IAS 16 "Property, plant and equipment" and IAS 38 "Intangible assets", it wouldn't be able to recognize any assets used in prospecting and evaluation of mineral resources. Besides, proceeding from the circumspection concept laid in the Framework of preparing financial reporting based on international standards and taking into account the ambiguity of the future prospective, the expenditure in the area of natural resources development should be included into the financial result of the period during which they were made, which will lead to the distortion of the perception of real dynamics.

On the stage of development the financial result is going to be understated, because from the current income there will be deducted the expenditure carried out for the future, but for not the current earnings. On the stage of mining operation the financial result is oppositely going to be overstated, because from the recovered mineral products sales there will be deduced only the expenditure necessary to carry out the very process of mining. Significant expenditure incurred mostly to carry out the mining process is not counted, and the cost value becomes incomplete. This kind of approach goes in conflict with the set world practice of accounting in extracting sector.

In this respect there appeared a necessity to accept a separate standard of IFRS 6 "The exploration for and evaluation of mineral resources", which allows some deviations from the conceptual principles of IFRS.

\section{Materials and Methods}

The theoretical basis for the investigation is based on the fundamental accounting concepts, hypotheses and approaches of classical and modern scientific economic literature. Then the methodological basis of the work is the comprehensive approach to the investigated processes and phenomena, the techniques of dialectic and formal logics. We used a wide range of methods: comparative analysis, synthesis, systematization and generalization of the theoretic materials, 
consolidation and grouping, analytical proceedings and other methods.

\section{Results and Discussion}

Only part of the expenditure connected with mineral resources and allocated to the stage of prospecting and evaluation of mineral resources gets under IRSF 6 regulation. The costs incurred before the rights to prospect and evaluate were procured as well as the costs incurred after the fact of technical feasibility and commercial practicality of mining operations has been set are not regulated in IFRS 6 . The graphic display of IFRS 6 regulating sphere is presented in figure 1.

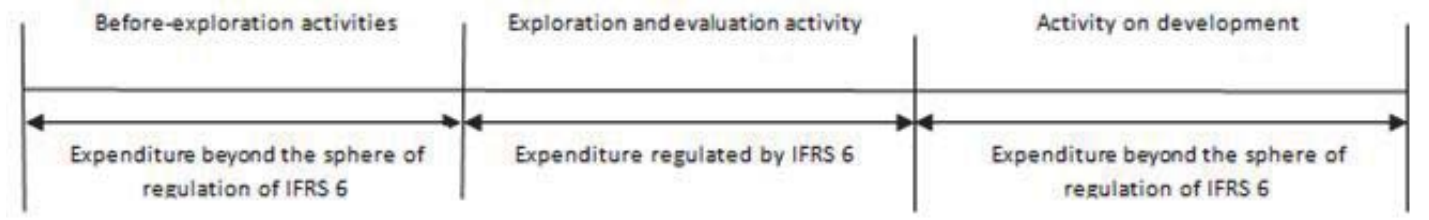

Fig.1 The sphere of regulation of IFRS 6 "The exploration for and evaluation of mineral resources"

So, the enterprise has to develop the accounting policy for a separate display of expenditure referring to each stage of the usage of mineral resources in extractive industries:

- Activities on exploration and evaluation of mineral resources;

- Before-exploration activity;

- Activity on development and extraction.

Future possible economic benefits from the exploration of mineral resources are not always obvious. One needs to rely on professional judgment [11]. It is possible to use the results of project review done by senior managers or an authorized body, or business-plan, medium terms of an agreement concluded on other projects, political situation, argumentativeness of the territory, commercial aspects, tax and judicial peculiarities, etc. In other words, on the stage of before-license prospecting of hydrocarbons the expenditures appearing before taking the decision on the project technical feasibility and the organization's interest in procuring the rights on subsurface resource management should be expensed as incurred [14]. And expenditures appearing after such decision has been taken should be included in the cost of the rights on subsurface resource management.

In accordance with $\S 9$ IFRS 6 an enterprise should work out the accounting policy defining the expenditures which will be accepted as assets connected with exploration and evaluation, and practice consistent application of accounting policy [10]. The judgment made at this has to be based on the data about the connection between making charges and finding out particular mineral reserves. International standards offer an approximate list of expenditures which might be included into the primary measurement of active assets connected with exploration and evaluation:

- Procurement of rights on carrying out prospecting works;

- Topographical, geological, geochemical and geophysical investigations;

- Prospecting and exploring drilling;

- trenching;

- selection of tests and samples;

- activity on evaluation of technical feasibility and commercial practicality of mineral resources exploration [3].

So the organization carrying out expenditures on exploration and evaluation of mineral resources has to provide in its policy the conditions to recognize the assets on exploration and evaluation of mineral resources in accordance with $\S$ 10 IAS 8 "Accounting policies. Changes in accounting estimates and errors". It is necessary for the accounting policy to provide the kinds and content of expenditures the organization recognizes as assets in exploration and evaluation of mineral resources taking into account the degree of their correlation with the exploration of particular mineral resources.

The recognition of assets of exploration and evaluation stops at the moment when the technical feasibility and commercial practicality of the mineral resources mining on a particular mineral resources block have been proved, or from the moment when mineral resources mining on a particular site has been proved as having no prospect. [6]. In this respect it is necessary to mark in the accounting policy the particular criteria and a list of documents on the basis of which one makes the decision that the technical feasibility and commercial practicality of the mineral resources mining on a particular mineral resources block are considered as proved, or mineral resources mining on a particular site is regarded 
as having no prospect. It is recommended that the accounting policy should reveal the information about the periodicity of evaluation and setting the criteria of technical feasibility and commercial practicality of mining on a site. The criteria might be finding out resources on the site, availability of the specified data about the geologic structure and resources reserves and carrying out the test operation to get the data and parameters to work out a technological scheme for working of mines, etc.

After the decision that mining operations are economically viable has been taken, the exploration and evaluation assets need to be reclassified [1]. If the exploration and evaluation expenditures are effective, corresponding assets should be transferred into the category of development assets. Ineffective exploration and evaluation expenditures should be written down up to the fair value with the deduction of expenditures on costs to sell, because it's impossible to use the concessionary terms, which allows to group these assets with the ones on mining operations in the framework of a bigger unity generating monetary means [8].

For example, the 2014 accounting policy of JSC "OC Rosneft" makes provisions for "the expenditures on exploration including expenditures on geological and geophysical works and carrying a dry hole are allocated to the expenses of the period when these expenditures were made. The cost of exploration wells (including stratigraphic ones) are temporarily capitalized till oil and gas reserves are found out by implementing the drilling programme. The length of period of time necessary to carry out such an analysis depends on technical peculiarities and economic difficulties in making an evaluation of resources extraction. If the conclusion is made that the wellhole carries such amounts of oil that it might be ineffective to produce it, the wellhole expenditures are written down to the costs of the corresponding period of time in the "Expenditures on exploration and evaluation of mineral resources" section.

The jurisdiction of the accountant's professional judgment includes establishing the order of classification of assets of exploration and evaluation as tangible or intangible proceeding from the essence of recognized assets [15]. While establishing weather to classify assets of exploration and evaluation as tangible or intangible assets of exploration and evaluation it should be taken into account the creation of what object the expenditures are allocated to most [4]. If the expenditures on exploration and evaluation are allocated to the object having a physical shape which will be used as an independent asset, then the asset may be classified as the tangible asset of exploration and evaluation. If the expenditures lead to getting information about creating the assets of exploration and evaluation of mineral resources on a particular subsurface site, then this kind of an asset should be classified as intangible asset of exploration and evaluation [2].

Exploration and evaluation assets are recognized by the production cost, i.e. actual expenditures [7]. The organization acknowledges any liabilities connected with the destruction of objects and rehabilitation of environment, mineral resources, which it suffers for some period of time as the result of performing works on exploration and evaluation of mineral resources.

In this case there might arise some difficulties in figuring out a reliable assessment of the cost of exploration and evaluation of mineral resources. In this respect it is recommended that one should use the International Valuation Standards in extractive sector worked out by International Valuation Standards Committee.

Within the jurisdiction of accountant's professional judgment there fall the choice of the model of the further evaluation of the assets connected with the exploration and evaluation of mineral resources:

- by original cost;

- by revalued amount (as prescribed in IFRS 16 for assets revaluation or in IAS 38 for intangible assets revaluation depending on the classification of assets).

Revaluation of the assets is possible only when they are submitted to reliable fair value measurement. The revaluation should be carried out regularly to provide the correspondence of the balance sheet value of the object to the one which is defined by the fair value applied to it on the date of evaluation [9]. The usage of the model of assets revaluation in exploration and evaluation of mineral resources doesn't exclude systematic amortization charges and calculations on impairment, but each date of revaluation the original assets cost changes: it either increases or decreases in accordance with the carried revaluation.

At the same time the alternative procedure of the further evaluation of intangible assets on revalued amount provided in § 10 IFRS 6 "The exploration for and evaluation of mineral resources" is limited by the cases when fair value is determined on the basis of active market data. In fact, active market exists only for quotas to extract a particular quantity of minerals [16]. But the right to unlimited site development is always unique, that is why even theoretically these rights can't have an active market, consequently, this model of revaluation of intangible assets can't be applied.

The assets connected with exploration and evaluation of mineral resources should be tested for impairment in case there appear some circumstances which will testify that balance sheet assets may exceed its recoverable amount [12]. Since it might be hard to apply the standard impairment testing procedure before the commercial practicality of the 
exploration has been proved, IFRS 6 sets a particular list of possible facts speaking for the necessity to carry an impairment test.

Due to the fact that the list is open-ended in the accounting policy it is possible to foresee some other factors specific for the particular enterprise which speak for the impairment. Besides, the enterprises have to determine the level of the impairment test (the monetary means generating unit or a group of such units).

The enterprises are allowed to group exploration and evaluation assets together with the recovery ones if there is a distinct accounting policy regarding such grouping, and the policy is practiced consistently from period to period. The only restriction is the claim that the monetary means generating unit or a group of such units should not be bigger than the segment defined by IFRS 8 "Operating Segments".

However, when the exploration and evaluation assets have been reclassified and transferred into another category they should fall under the usual testing procedure in accordance with IAS 36 "Impairment of Assets" at the level of monetary means generating unit and amortization at the level of separate assets [13]. In this case the impairment testing and amortization of the group of assets are impossible.

As an example we will give an extract from the accounting policy principles description of JSC "Lukoil" taken from the Notes to consolidated interim financial reporting, drawn up for the period of 6 months up to the date of June, 14 2014: "Long-term assets, such as oil- and gas-producing fixed assets are evaluated in terms of possible impairment when some events or discontinuance of circumstances point out that there is a possibility that the balance sheet assets might not be compensated. Recompensation of the assets cost is estimated by comparing the book value of the group of assets and the predicted value of the future non-discounted cash flows generated by this group of assets. In those cases when the balance sheet assets exceed the predicted value of the future non-discounted cash flows one has to admit the impairment loss by the write-off of the balance sheet value to the predicted fair market value of the group of assets, which is usually defined as the net worth of the future non-discounted cash flows".

The elicited impairment loss is allocated to profits and losses before carrying out the reclassification and exclusion of the exploration and evaluation assets items from the assets. Some tangible assets can be reclassified into the category of fixed assets and general industrial stocks [1].

The disclosure of information about the exploration and evaluation of mineral resources is obligatory from the point of view of explanation of separate indicators of the financial data reporting. In particular, an accepted order of assets recognition is uncovered, and also total assets, value of liabilities, amount of income and expenses, operational and investment cash flows which arise while carrying out operations on exploration and evaluation of mineral resources. Despite IFSR 36 lapse from a whole set of International standards, the disclosure of information about the accounting policy concerning the expenditures and assets on exploration and evaluation of mineral resources should be carried out in accordance with IAS 8 "Accounting policies, changes in accounting estimates and errors".

\section{Conclusion}

So, the application of the accountant's professional judgment while shaping information about exploration and evaluation of mineral resources for financial data reporting is necessary to admit, classify, make a preliminary and more detailed judgment. The recommendations offered in the article will allow to shape the accounting policy of oil producing companies in the optimal way and to raise the quality of disclosure of the information about the mineral resources mining.

\section{References}

Billio M., Getmansky M., Lo A., and Pelizzon L. Econometric Measures of Connectedness and Systemic Risk in the Finance and Insurance Sectors.// Journal of Financial Economics 3, 2012, vol. 104, pp. 535-559

Erickson J. D., Messner F, Ring I. Ecological Economics at the Watershed Scale: Comparing and Contrasting the United States and German Experiences and Approaches, in Jon D. Erickson, Frank Messner, Irene Ring (ed.) Ecological Economics of Sustainable Watershed Management (Advances in the Economics of Environmental Resources, Volume 7) Emerald Group Publishing Limited, pp.3 - 7

Gowdy, J., 1994. Coevolutionary Economics: The Economy, Society and the Environment. Kluwer Academic Publishers, Dordrecht.

Jeffrey T. Doyle, Matthew J. Magilke. Decision Usefulness and Accelerated Filing Deadlines // Journal of Accounting Research. Vol. 51, No. 3 (june 2013), pp. 549-581(DOI: 10.2307/23473300)

Kulikova L.I., Semenichina N.B. Preparation of the actuarial balance sheet based on the present value of assets and liabilities of the going concern. Life Science Journal. 2014;11(11s):603-607.

Lang M, Lins K. V. and Maffet M. Transparency, Liquidity, and Valuation: International Evidence on When Transparency Matters Most // Journal of Accounting Research. Vol. 50, No. 3 (JUNE 2012), pp. 729-774 (DOI: 10.2307/41477990) 
Merton R. C., Billio M., Getmansky M., Gray D., Andrew W. Lo, Pelizzon L. On a New Approach for Analyzing and Managing Macrofinancial Risks (corrected) // Financial Analysts Journal. Vol. 69, No. 2, 2013

Munro, A., 1997. Economics and biological evolution. Environmental and Resource Economics, vol. 9 pp. $429-449$.

Ozbekhan, H., 1969. Towards a general theory of planning. In: E. Jantsch (ed.), Perspectives of Planning. OECD, Paris, pp. 31-50.

Rennekamp K. Processing Fluency and Investors' Reactions to Disclosure Readability // Journal of Accounting Research. Vol. 50, No. 5 (DECEMBER 2012), pp.1319-1354 (DOI: 10.2307/41680547)

Shahid Ebrahim M., Sourafel Girma, Eskandar Shah M., Jonathan Williams. Dynamic capital structure and political patronage: The case of MalaysiaOriginal Research Article// International Review of Financial Analysis. Volume 31, pp. 117-128.

Siebert, H., 1985. Spatial aspects of environmental economics. In: A.V. Kneese and J.L. Sweeney (eds.), Handbook of Natural Resource and Energy Economics, vol. 1. North-Holland, Amsterdam.

Siebert, H., 1995. Economics of the Environment: Theory and Policy, 4 rd ed., Springer-Verlag, Berlin.

Stephen C. Sexauer and Laurence B. Siegel. A Pension Promise to Oneself // Financial Analysts Journal 6, 2013, Volume 69, pp. 13-32

Sungjun C. New return anomalies and new-Keynesian ICAPM. International Review of Financial Analysis, Volume 29, September 2013, pp. 87-106 (DOI: 10.1016/j.irfa.2013.04.003)

Thomas J. S. Rational Expectations and Ambiguity (corrected) // Financial Analysts Journal, March/April 2014, Vol. 70, No. 2 . pp. 1419. 